\title{
Research in Petroleum and Environment: A Bibliometric Analysis in South America
}

\author{
Gricelda Herrera-Franco ${ }^{1,2^{*}}$, Néstor Montalván-Burbano ${ }^{3,4}$, Carlos Mora-Frank ${ }^{1,4}$, Lucrecia Moreno-Alcívar ${ }^{1}$ \\ ${ }^{1}$ Facultad de Ciencias de la Ingeniería, Universidad Estatal Península de Santa Elena (UPSE), Avda. principal La Libertad- \\ Santa Elena, La Libertad 240204, Ecuador \\ ${ }^{2}$ Geo-Recursos y Aplicaciones GIGA, ESPOL Polytechnic University, Campus Gustavo Galindo Km 30.5 Vía Perimetral, \\ Guayaquil 09-01-5863, Ecuador \\ ${ }^{3}$ Business and Economy Department, University of Almería, Ctra. Sacramento s/n, La Cañada de San Urbano, Almería 04120, \\ Spain \\ ${ }^{4}$ Centro de Investigación y Proyectos Aplicados a las Ciencias de la Tierra (CIPAT), ESPOL Polytechnic University, Campus \\ Gustavo Galindo Km 30.5 vía Perimetral, Guayaquil 09-01-5863, Ecuador
}

Corresponding Author Email: grisherrera@upse.edu.ec

https://doi.org/10.18280/ijsdp.160612

Received: 23 June 2021

Accepted: 27 September 2021

\section{Keywords:}

bibliometric analyse, petroleum, environment, knowledge mapping, South America

\begin{abstract}
Petroleum is a crucial resource that has globally influenced the scientific community and socio-economic development. However, its industrial processes negatively affect the natural environment. This research aims to analyse the intellectual structure of the petroleum and environment relationship in South American countries' contributions through bibliometric methods. The study presents a methodology: i) establishing search criteria; ii) initial search results; iii) refinement of results; iv) data analysis. Bibliometric methods were incorporated to analyse the performance of scientific production, and its mapping, allowing to reveal its structure. The results show a growth of this field of study (538 articles) through the contribution of countries, institutions and authors. Most of the studies related to oil and environment carried out by Brazil (399 articles) have a strong collaboration with Argentina, Colombia and Uruguay and partnerships with countries outside the region such as the United States, United Kingdom, and Spain. In addition, seven research themes were found (Biomarkers-petroleum derivatives, bioremediation, bioproductive processes, hydrocarbonenvironmental, pollution effects, mangrove pollution, oil spill-simulation). This study provided relevant information on environmental pollution reflected in diverse sectors of South America (coastal and Amazonian areas). It showed several environmental remediation methods focused on microorganisms, biosurfactants, microbial residues, ionic processes and phytoremediation. Therefore, this research allows us to obtain meaningful and current information on the art state in this field of study.
\end{abstract}

\section{INTRODUCTION}

Petroleum has been fundamental during the 20th century and continues to be so in the 21 st century, as it is considered a vital resource that sustains modern society and the world economy [1]. Petroleum is an essential resource in the industrial and geopolitical circle. It is the base for energy production in developed and developing countries, supplying $33.1 \%$ of consumption worldwide [2]. Industries linked to petroleum production benefit economically, increasing the labour rate [3]. The oil price falls negatively impact the economy, reflected in the Gross Domestic Product (GDP), linked to the resource's exports [4]. In industry, petroleum goes through various processes such as exploration, drilling, production, transportation, refining, distribution, and storage [5]. After the procedure, fuels and raw materials are obtained, such as gasoline, diesel, lubricants, pesticides, construction materials, consumer products and medicines [6].

The extensive consumption of petroleum hydrocarbons has a strong demand that encourages developing various industrial processes, such as operational management and transportation for commercial functions [7]. These activities generate greenhouse gases and alterations in geobiological environments, which cause damage to nature [8]. On the other hand, geobiological alterations occur in the environment: i) the soil is contaminated by spills or toxic waste, causing damage to its structure, organic loss and nutrients [9]; ii) water, hydrocarbons deteriorate various aquatic ecosystems, such as seabed, groundwater and the hydrological system [10]; iii) the air, where pollutants compromise its quality from the petrochemical industry as it receives greenhouse gases and volatile organic compounds, altering the environment [11]. Oil pollution in geobiological environments occurs mainly by leaks, industrial processes, underground reserves, accidents in the transport of resources, and waste disposal, destroying ecosystems and emitting toxic components to living beings' health [12].

The oil industry integrates sustainability approaches into its industrial activities, including observing the Sustainable Development Goals (SDGs), like health and well-being (SDGs 3 ), access to water (SDGs 6), affordable energy and friendly (SDG 7), economic progress and innovation (SDGs 8-9), 
climate action, underwater and terrestrial life (SDGs 13-15) [13]. These relationships are challenges of new trajectories faced by the oil industry to monitor industrial processes [14]. These challenges are solutions to environmental problems through scientific approaches, such as remediable physicalchemical and biological methods, sustainable development strategies (projects), Eco-innovation (technological and nontechnological), and energy development [15-17].

The relationship between petroleum and the environment is discussed in developed and undeveloped countries, including countries in South America with petroleum production and consumption, such as Venezuela, Brazil, Colombia, Ecuador, Peru and Argentina [2, 18]. These are among the planet's megadiverse, and their natural environment is affected by petroleum activities [19]. Among the significant environmental damages are Amazonian pollution caused by spills of toxic substances and gas emissions and natural alterations in fresh and marine water ecosystems [20, 21].

Various studies have been presented on the petroleumenvironment relationship in different regions, countries, or contexts, so a study covering a better understanding of this area's knowledge structure is relevant. Thus, the study aims to complement other works' contributions by presenting a bibliometric analysis on this study field. This analysis is a quantitative method that explores the impact of a specific science field [22]. In addition, the study considers collecting scientific articles from South America. This region has excellent natural resource potential in geodiversity and biodiversity terms globally (recognised by world organisations) [23]. The challenge for developing countries is to find possible mechanisms for sustainability [24]. A bibliometric study will allow knowing the environmental contamination problems generated by hydrocarbons in sectors of the region and the different topics of environmental remediation. This allows us to pose several research questions: there is a growth in scientific production in the petroleum and environment relationship? What are the most cited documents? What are the authors and countries that allowed the construction of this field of study?

This study aims to carry out a bibliometric review of the Scopus base's petroleum-environment relationship during 1990-2020. The review allows the structural knowledge of the subject in South American countries through bibliometric methods. The study developed in five sections: introduction, contains the context of the relationship between petroleum and the environment; the methodology shows a systematic scheme for the process and analysis of information; results, details the data obtained and its respective comment; discussion, criteria are stipulated based on the results obtained in the study; finally, the conclusions and references used.

\section{MATERIALS AND METHODS}

Systematic literature reviews are fundamental in developing knowledge in a specific area through a rigorous and transparent procedure, allowing the identification, processing and analysis of scientific production considered relevant to the study [25]. Bibliometric studies exhibit a formal outline of rigorous methodology, similar to the previous literature reviews [26]. Bibliometrics is a scientific field that allows the scientific production evaluate using statistical and mathematical methods [27]. These studies make it possible to assess the intellectual structure of the study field through performance analysis with authors, countries and institutions [28]. In addition, the bibliometric mapping (science maps) allows observing the connections in the structure, the various disciplines interrelation and study fields [29].

This study presents a methodological process consisting of four stages (see Figure 1): i) search criteria, ii) initial search results, iii) refinement of results, and iv) data analysis.

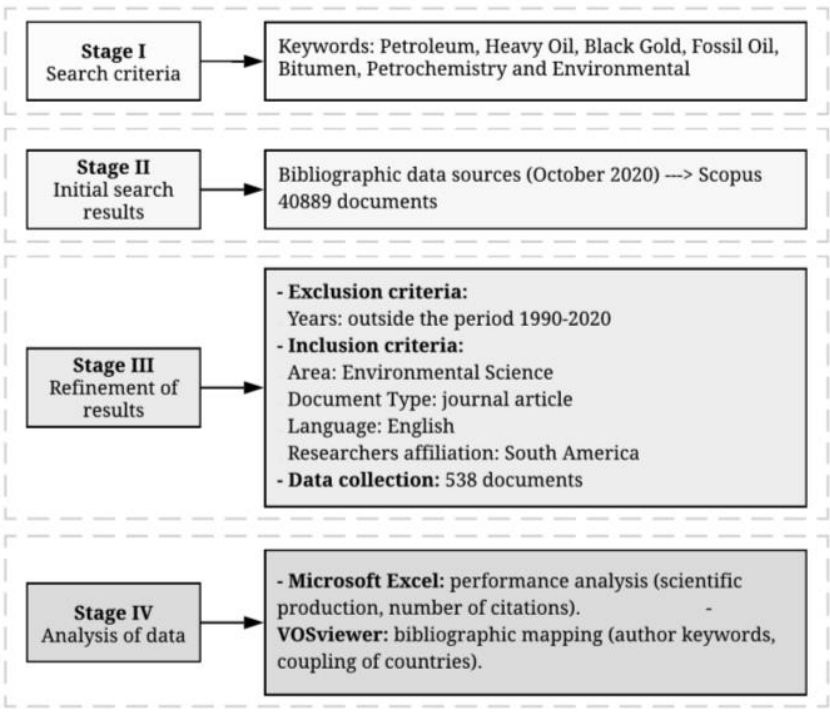

Figure 1. Methodological outline of this research

Stage I-Search criteria: it is essential to structure the search for information by using keywords and search parameters. The terms used are "petroleum", "heavy oil", "black gold", "fossil oil", "bitumen", "petrochemistry". Terms frequently used in the oil industry [30]. The term "environmental" is usually related to topics in environmental sciences and is considered an interdisciplinary field. The terms selected show this relationship in studies with similar themes. The term "environmental" belongs to the interdisciplinary field of Environmental Sciences related to several studies about the oil industry [31].

Stage II-Initial search results: the study considered the Scopus database for the collection and processing of bibliographic information. In detail: i) it is considered the largest database of citations and abstracts with world coverage, ii) rigorous quality standards such as the Scimago Journal Rank (SJR), iii) ease of access, downloading and use of data, iv) bibliometric studies have been presented in various academic disciplines using the Scopus database has greater coverage in the area of Earth Sciences [32, 33].

The data were extracted from the Scopus database in October 2020, using the selected terms and the option "titles, abstracts and author keywords", in the following topic search $(\mathrm{TS})=($ "petroleum*" OR "heavy oil*" OR "black gold" OR "fossil oil" OR "bitumen" OR "petrochemistry" AND "environmental*"). In this initial search, 40889 documents were obtained.

Stage III-Refinement of results: this stage establishes exclusion and inclusion criteria for the processing and refinement of the information collected. Documents outside the period 1990-2020 were excluded and limited to "Environmental Science" as the subject area of this research. Obtaining 13963 documents. Subsequently, articles in English were considered due to their representativeness in scientific production and that they have been reviewed by blind peers, 
which ensures their quality [26] obtaining 9756 articles. Finally, it has considered delimiting the documents related to affiliations in South American's countries, obtaining 542 articles.

Stage IV-analysis of data: the information obtained was downloading from the Scopus database in CSV (comma separated values) format. These data include variables related to the author's bibliography and his work, affiliation, keywords and references. Data requires pre-processing and refining of data outliers (cleaning of errors and duplicates) to ensure information quality [22]. They are obtaining 538 articles.

Finally, the processed data are used to carry out the bibliometric analysis, which involves two essential procedures:

(1) The scientific production's performance analysis carried on its various groups of scientific actors (researchers, papers, affiliations) and the impact of their activity. Microsoft Excel software was used to carry out these analyses and preprocessing [26].

(2) Bibliometric mapping, considered a modern technique to analyse the study field's intellectual structure. This structure is examined through the co-occurrence of Author Keywords y bibliographic coupling of countries [29]. The construction of these maps done using the VOSviewer software (University of Leiden, Netherlands) allows the construction, exploration and visualisation of two-dimensional (2D) bibliometric networks that are easy to interpret and apply in a specific study field [34]. This software has been used in a variety of scientific disciplines.

\section{RESULTS}

\subsection{Performance analysis}

\subsubsection{Analysis of scientific production}

Figure 2 shows the scientific production of articles between 1990-2020, with a total of 538 articles. The figure shows exponential growth from 2010 onwards, which is corroborated using Price's Law [22]. This law is a bibliometric indicator that makes it possible to determine whether the elements studied are a field of study by showing exponential growth in their production. For this purpose, a linear model $\left(y_{1}=2.0924 \mathrm{x}\right.$ 4179.6) and an exponential model ( $\left.y_{2}=1 \mathrm{E}-119 \mathrm{e} 0.1376 \mathrm{x}\right)$ were established. The coefficient of determination $\left(R^{2}\right)$ shows a higher value for the exponential model $\left(R^{2}=0.8768\right)$ concerning the linear model $\left(R^{2}=0.8337\right)$.

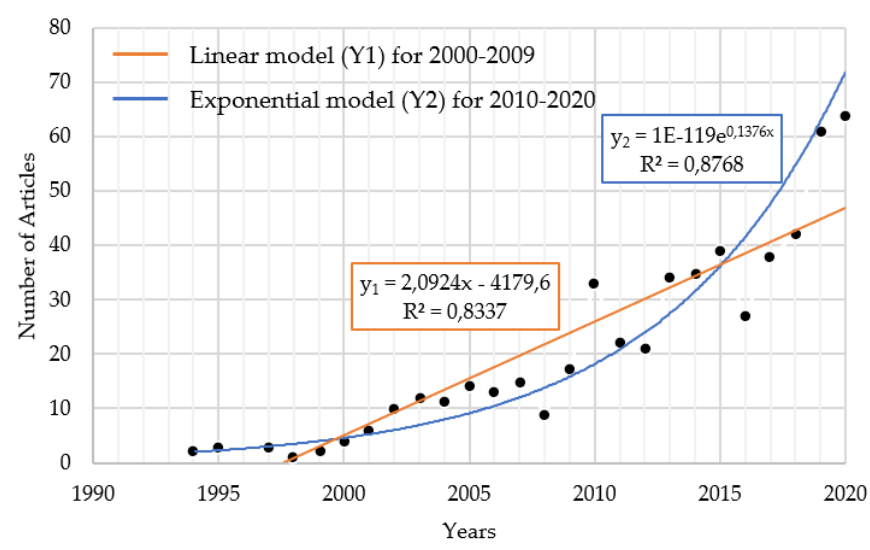

Figure 2. Scientific production development

\subsubsection{Frequently cited documents}

The most cited papers correspond to the most influential in the study field. Overall, the 538 papers have an average of 23.5 citations, where $2.9 \%$ of the manuscripts have more than 100 citations, $44.1 \%$ between 11 and 100 citations, $43.1 \%$ between one and ten citations, and $9.9 \%$ have no citations. Table 1 shows the fifteen most cited documents. The first is by Bento et al. [15] (422 citations), who report on oil bioremediation by introducing microorganisms to analyse biological behaviour at contaminated sites. The second is by Readman et al. [10] (411 citations) carried out a study of pollution in the Black Sea, identifying the types of pollutants. The third article is by Annunciado et al. [35] (328 citations) shows various methods to control oil spills.

\subsection{Bibliographic mapping}

\subsubsection{Author keyword co-occurrence network}

The co-occurrence analysis is a technique that allows us to understand the relationship of the keywords that appear in the set of publications in the field of study [26]. The VOSviewer was used for network representation, revealing cognitive structure [34]. Were extracted 1705 author keywords from the database, where 53 co-occurred at least five times.

Table 1. Most cited documents on the petroleum-environment relationship.

\begin{tabular}{|c|c|c|}
\hline Authors & Titles & Cites \\
\hline Bento et al. [15] & $\begin{array}{c}\text { Comparative bioremediation of soils contaminated with diesel oil by natural attenuation, } \\
\text { biostimulation and bioaugmentation }\end{array}$ & 422 \\
\hline Readman et al. [10] & Petroleum and PAH contamination of the Black Sea & 411 \\
\hline Annunciado at al. [35] & Experimental investigation of various vegetable fibres as sorbent materials for oil spills & 328 \\
\hline Santos et al. [9] & $\begin{array}{c}\text { Heavy metal contamination in coastal sediments and soils near the Brazilian Antarctic Station, King } \\
\text { George Island }\end{array}$ & 217 \\
\hline Muniz et al. [36] & $\begin{array}{c}\text { Assessment of contamination by heavy metals and petroleum hydrocarbons in sediments of } \\
\text { Montevideo Harbour (Uruguay) }\end{array}$ & 163 \\
\hline Cerqueira et al. [37] & Biodegradation potential of oily sludge by pure and mixed bacterial cultures & 152 \\
\hline Medeiros et al. [38] & Natural and anthropogenic hydrocarbon inputs to sediments of Patos Lagoon Estuary, Brazil & 139 \\
\hline $\begin{array}{l}\text { Medeiros \& Caruso Bícego } \\
\text { [39] }\end{array}$ & $\begin{array}{c}\text { Investigation of natural and anthropogenic hydrocarbon inputs in sediments using geochemical } \\
\text { markers. I. Santos, SP - Brazil }\end{array}$ & 127 \\
\hline Simonato et al. [40] & $\begin{array}{c}\text { Biochemical, physiological, and histological changes in the neotropical fish Prochilodus lineatus } \\
\text { exposed to diesel oil }\end{array}$ & 127 \\
\hline Trindade et al. [41] & $\begin{array}{c}\text { Bioremediation of a weathered and a recently oil-contaminated soils from Brazil: A comparison } \\
\text { study }\end{array}$ & 121 \\
\hline
\end{tabular}

Figure 3 shows 52 nodes in seven clusters interconnected by links (connector linking node to node): Cluster 1,
"Biomarkers-Petroleum derivatives" (red). The most important focal term is Biodegradation; the other minor ones 
are biomarker y life cycle assessment. Papers including these terms provide information on the use of biomarkers in polluted waters for the detection of petroleum and oil derivatives, as well as impact assessments of oil spills and studies on the effect of gasoline on marine organisms [36, 42]. Cluster 2, "Bioremediation" (green), is related to the term bioregeneration, like phytoremediation of oil-contaminated sites, microorganisms, weathering $[15,43]$. Cluster 3 , "Bioproductive processes" (blue), consists of 8 nodes, and its essential keywords are petroleum, biosurfactant, comet assay, crude oil, and produced water. This cluster contains studies like bioremediation of contaminated soils using biosurfactants, microbial waste and ionic processes [41, 44, 45]. Cluster 4, "hydrocarbon-environmental" (yellow), consists of 8 nodes whose associated terms are polycyclic aromatic hydrocarbons, hydrocarbon, environmental monitoring, and others. The terms relate to studies: the use of techniques to assess fractional and individual hydrocarbons, as well as polycyclic aromatic hydrocarbons and phytoremediation in contaminated soils $[46,47]$.

The remaining clusters are composed as follows: Cluster 5, "Pollution effects" (purple), with studies related to pollution in cities and rural areas, and effects on vegetation [35, 48]; Cluster 6, "Mangrove pollution" (light blue) consists of 3 nodes, show investigations with terms of Pollution [9, 40], hydrocarbon degradation and mangrove [41, 49]; Cluster 7, "Oil spill-simulation" (orange) is the smallest cluster with only two nodes; however, it contains the term Oil Spill, which has a large magnitude. The words are related to oil spill remediation methods and oil spill pre-deduction [35].

The polycyclic aromatic hydrocarbons and hydrocarbon nodes show a higher magnitude than the others, with research related to assessing petrochemical compounds on environmental surfaces due to petroleum contamination [10,
36]. There is a high relationship between clusters $1-4$ and 7 , as some overlap. The keyword crossover contains polycyclic aromatic hydrocarbons, hydrocarbon, petroleum, biodegradation, bioremediation and oil spill. These terms relate to studies on biodegradable-bioremediate methods for oil spill contamination $[15,35]$.

\subsubsection{Country Bibliographic Coupling Network}

Bibliographic Coupling Network analysis allows visualising the connection of countries that maintain scientific collaboration [26]. In the construction of the bibliographic map are the countries with three or more citations. Figure 4 shows the bibliographic network composed of 27 countries integrated into seven clusters.

The bibliographic coupling network principal exponent is Brazil, with 399 documents shows a collaborative system with 26 countries. The present contributions studies on contaminant assessments of petroleum-derived compounds in soil, air and water in different Latin American places [38, 39], as well as evaluations of anthropogenic materials [36], monitoring of oilcontaminated areas and the use of organisms for the assessment of pollutants by oil industries $[10,50]$. The second node is the United States, registering contributions with Brazil, Chile and the United Kingdom, contains studies of polluted air quality caused by urban transport fuel [51] and bacterial application for bioremediation of petroleum [15]. The third country is Argentina, with 56 articles and 25 countries connected in its scientific co-collaboration register. This nation shows strong collaboration with Brazil and the United States, with research on marine animals affected by oil pollution on the South American continent, remediation using culture and molecular tools, anthropogenic hydrocarbon impact assessments in the south of the American continent [9, $36,49]$.

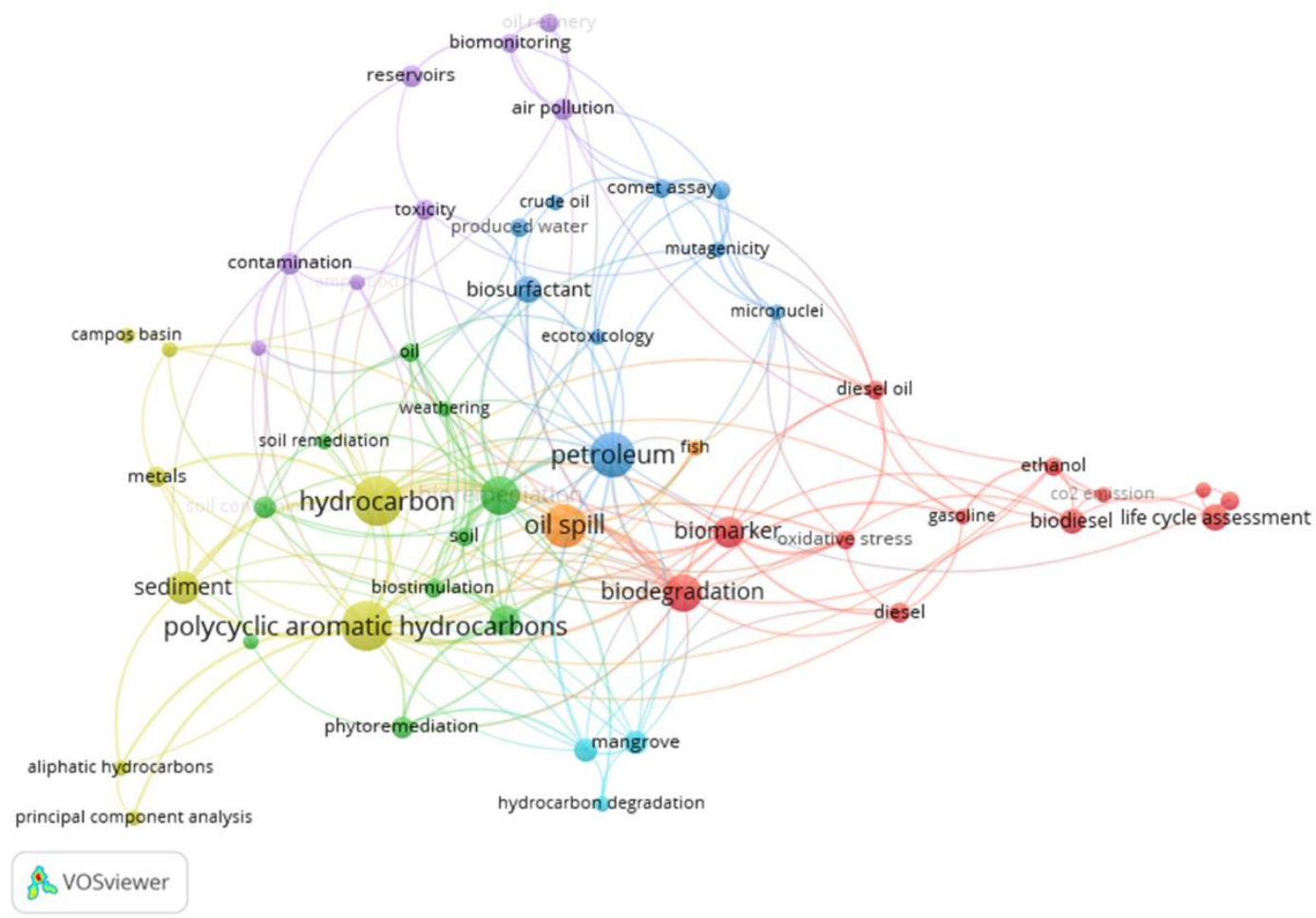

Figure 3. Visualisation of the co-occurrence map of Author Keywords 


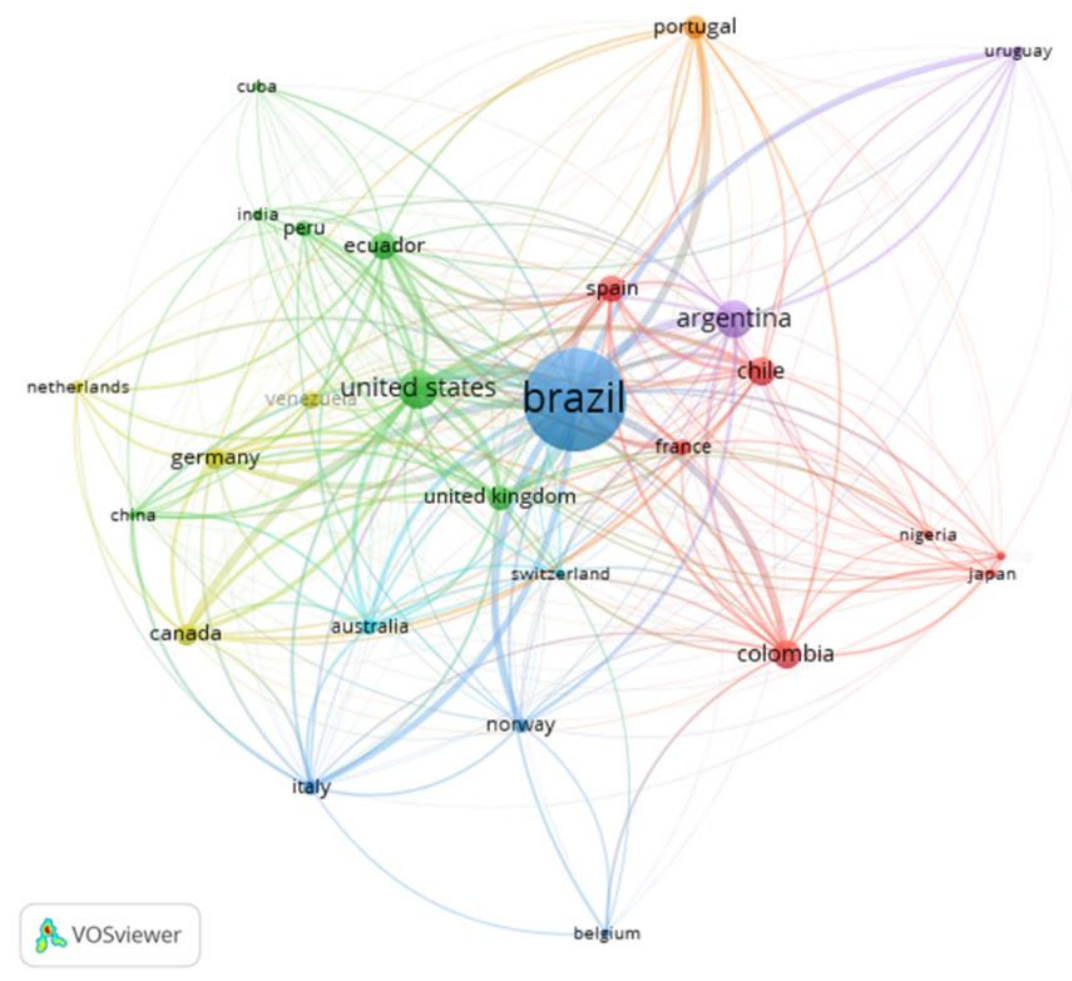

Figure 4. Bibliographic Coupling Network of countries

In addition, other smaller contributions are shown with Brazil. In collaboration with Colombia, work is shown on petrochemicals and environmental pollution solution methods, like exergy based on industrial processes and fuel consumption [11], treatment of polluted water by PhotoFenton [52], and identification of particles emitted in industrial processes [53]. Uruguay, with studies related to biochemical analysis and the quality of the natural environment, like assessment of heavy metals, organic contamination in surface sediments and coupling of biological and chemical proxies of the benthic habitat $[36,54]$. Finally, Chile present studies related to the examination of penguins affected by oil spills [55] and biodiesel production related to the application of oilethanol miscella [56].

\section{DISCUSSION}

The present research carries out a bibliometric analysis of the petroleum-environment relationship over the last three decades. This study focuses on the scientific production of South American countries, where their oil activity impacts the natural environment [19]. The analysis allows knowing the intellectual structure of this field of study through the most cited documents, keywords, authors, and country contributions.

The environmental concern about oil activity in this region appears in its first studies in 1994, increasing exponentially to 538 documents in 26 years (Figure 2). This importance is demonstrated when reviewing the production at the world level with an increase of 13.44 times, while the investigations of the South American region are significant (48.91 times) (see Table 2). We consider that with the above information, examining this intellectual structure in South America is pertinent.

Table 1 shows that the top 10 most cited papers have an affiliation with Brazilian authors. Of these works, five are international collaborations [10, 15, 36, 38, 39], and five are national collaborations $[9,35,37,40,41]$. The most prominent authors are Bícego M.C., from the Universidade de Sao Paulo - USP (Brazil) with three papers [36, 38, 39], and Medeiros P.M., from the University of Georgia (United States), who has two articles with Bícego M.C. [38, 39].

Table 2. Scientific production at a regional and global level

\begin{tabular}{cccccc}
\hline \multirow{5}{*}{ Articles by periods } & Increase & Total \\
Region & $\begin{array}{c}\mathbf{1 9 9 0 -} \\
\mathbf{1 9 9 9}\end{array}$ & $\begin{array}{c}\mathbf{2 0 0 0} \\
\mathbf{2 0 0 9}\end{array}$ & $\begin{array}{c}\mathbf{2 0 1 0 -} \\
\mathbf{2 0 2 0}\end{array}$ & $\begin{array}{c}\mathbf{1 9 9 0 / 2 0 2 0}) \\
\text { documents }\end{array}$ \\
\hline $\begin{array}{c}\text { World } \\
\text { regions }\end{array}$ & 738 & 2284 & 6900 & 13,44 & 9922 \\
\hline $\begin{array}{c}\text { South } \\
\text { America }\end{array}$ & 11 & 111 & 416 & 48,91 & 538 \\
\hline
\end{tabular}

The analysis of the intellectual structure (Figure 3 ) allowed to know the central topics of the network. On the one hand, terms related to the oil industry are petroleum, hydrocarbon and polycyclic aromatic hydrocarbons, while terms related to the environment are oil spill, bioremediation and biodegradation [38, 48], and oil spills impacting the environment and the economy $[35,49]$. Therefore, research topics that counteract these environmental problems are presented, such as the application of biosurfactant methods, phytoremediation [47], ionic processes [45], remediable and degradable methods [43]. These topics are related in two clusters $(2,4)$, which, being close to each other, show the relationship between oil activity and remedial environmental treatment.

The bibliographic coupling map of the countries (see Figure 4) shows that Brazil is the centre of the structure with 399 articles (9071 citations) and 26 collaborative relationships. The contributions with Brazil has been carried out in studies with common themes, like evaluation of contaminating materials by petroleum derivatives and crude oil in natural 
areas $[10,36,42]$, remediation methods (bioremediation, biodegradation, phytoremediation) $[15,37,43,47,49]$, environmentally friendly energy resources (biodiesel), studies on wild animals in marine or terrestrial areas [55], and exergy analysis in the operational performance of industries and energy use [11].

\section{CONCLUSIONS}

The bibliometric analysis shows that there is a growth in scientific production with 538 articles. Its first publications appeared in 1994, and scientific interest began in 2010. In the second decade (2000-2009) are found the three most cited papers (Bento et al., Readman et al., Annunciado et al.) with a total of 1161 citations $(10.2 \%)$. In general, the production curve shows a growth adjusted to an exponential model, complying with Price's Law, showing that it is an academic field of study. The intellectual structure presents the following criteria: author keyword maps, author co-citation, journal cocitation, and country coupling. The topics hydrocarbon, polycyclic aromatic hydrocarbons, petroleum, oil spill, diesel, gasoline, and diesel oil, present a solid connection to bioremediation and biodegradation. Other topics like $\mathrm{CO}_{2}$ emission, reservoirs, basin fields, genotoxicity and biomonitoring have a weak relationship with this structure. This research carried out mainly by Brazil, Argentina and Colombia, with collaborations from countries outside the South American context that have marked the development of this field of study.

In general, bibliometric methods made it possible to show the different studies on environmental problems in oceans, glaciers and Amazonia, generated by oil industries, commercial companies and fossil energy consumption. Therefore, it is recommendable to strengthen the different remediation methods in contaminated sectors, which will reduce the loss of aerial, terrestrial and aquatic ecosystems. In addition, the strategy of promoting sustainable development in industrial innovation will make processes and energy consumption efficient and environmentally friendly.

This study allowed obtaining information related to protection, solution, and energy alternatives, where $47 \%$ of the works are related to environmental sciences. The study has some limitations: i) using the Scopus database and ii) it considers articles written in the English language. Despite these limitations, this study presents a rigorous methodology for selecting the study area's documents and descriptors and documents in peer-reviewed journals. This criterion has made it possible to offer a reference study for researchers and students in this field. Future research may consider expanding this study considering the limitations outlined above.

\section{ACKNOWLEDGMENT}

The preparation of this study counted with the collaboration of various scientific research projects, as the "Peninsula Santa Elena Geopark Project" of the UPSE University project with code no. 91870000.0000.381017; and the project "Factores Geoambientales de los Pozos Petroleros y su Incidencia en el Desarrollo Territorial en los Cantones Salinas y La Libertad de la Provincia de Santa Elena", code no: 91870000.0000.385428. We thank CIPAT-ESPOL for their support in this research.

\section{REFERENCES}

[1] Vassiliou, M. (2018). Historical Dictionary of the Petroleum Industry (Second Edi). Rowman \& Littlefield.

[2] Looney, B. (2020). bp Statistical Review of World Energy.

https://www.bp.com/en/global/corporate/energyeconomics/statistical-review-of-world-energy.html, accessed on Mar. 29, 2021.

[3] Mirzaei, A., Moore, T. (2016). Banking performance and industry growth in an oil-rich economy: Evidence from Qatar. Q. Rev. Econ. Financ., 60: 58-69. https://doi.org/10.1016/j.qref.2015.06.001

[4] Benedictow, A., Fjærtoft, D., Løfsnæs, O. (2013). Oil dependency of the Russian economy: An econometric analysis. Econ. Model., 32: 400-428. https://doi.org/10.1016/j.econmod.2013.02.016

[5] Daaou, M., Larbi, A., Martínez-Haya, B., Rogalski, M. (2016). A comparative study of the chemical structure of asphaltenes from Algerian petroleum collected at different stages of extraction and processing. J. Pet. Sci. Eng., $\quad$ 138: 50-56. https://doi.org/10.1016/j.petrol.2015.11.040

[6] Hsu, C.S., Robinson, P.R. (2017). Springer Handbook of Petroleum Technology. Cham: Springer International Publishing.

[7] Hsu, C.S., Robinson, P.R. (2019). Petroleum Science and Technology. Cham: Springer International Publishing.

[8] Erikstad, L. (2013). Geoheritage and geodiversity management - the questions for tomorrow. Proc. Geol. Assoc., $124(4)$ : 713-719. https://doi.org/10.1016/j.pgeola.2012.07.003

[9] Santos, I.R., Silva-Filho, E.V., Schaefer, C.E.G.R., Albuquerque-Filho, M.R., Campos, L.S. (2005). Heavy metal contamination in coastal sediments and soils near the Brazilian Antarctic Station, King George Island. Mar. Pollut. $\quad$ Bull., $\quad 50(2)$ : 185-194. https://doi.org/10.1016/j.marpolbul.2004.10.009.

[10] Readman, J., Fillmann, G., Tolosa, I., Bartocci, J., Villeneuve, J.P., Catinni, C., Mee, L.D. (2002). Petroleum and PAH contamination of the Black Sea. Mar. Pollut. $\quad$ Bull., $44(1)$ : 48-62. https://doi.org/10.1016/S0025-326X(01)00189-8

[11] Flórez-Orrego, D., da Silva, J.A.M., Velásquez, H., de Oliveira, S. (2015). Renewable and non-renewable exergy costs and $\mathrm{CO}_{2}$ emissions in the production of fuels for Brazilian transportation sector. Energy, 88: 18-36. https://doi.org/10.1016/j.energy.2015.05.031

[12] Arellano, P., Tansey, K., Balzter, H., Boyd, D.S. (2015). Detecting the effects of hydrocarbon pollution in the Amazon forest using hyperspectral satellite images. Environ. Pollut., 205 : 225-239. https://doi.org/10.1016/j.envpol.2015.05.041

[13] United Nations. Sustainable Development Goals. https://www.un.org/sustainabledevelopment/, accessed on Mar. 31, 2021.

[14] Matteo, C., Candido, P., Vera, R., Francesca, V. (2012). Current and future nanotech applications in the oil industry. Am. J. Appl. Sci., 9(6): 784-793. https://doi.org/10.3844/ajassp.2012.784.793

[15] Bento, F.M., Camargo, F.A.O., Okeke, B.C., Frankenberger, W.T. (2005). Comparative bioremediation of soils contaminated with diesel oil by natural attenuation, biostimulation and bioaugmentation. 
Bioresour. Technol., 96(9): 1049-1055. https://doi.org/10.1016/j.biortech.2004.09.008

[16] Lampikoski, T., Westerlund, M., Rajala, R., Möller, K. (2014). Green Innovation Games: Value-Creation Strategies for Corporate Sustainability. Calif. Manage. Rev., 57(1): 88-116. https://doi.org/10.1525/cmr.2014.57.1.88

[17] Herrera-Franco, G., Carrión-Mero, P., Mora-Frank, C., Caicedo-Potosí, J. (2020). Comparative analysis of methodologies for the evaluation of geosites in the context of the santa elena-ancón geopark project. Int. J. Des. Nat. Ecodynamics, 15(2): 183-188. https://doi.org/10.18280/ijdne.150207

[18] Martins, F., Felgueiras, C., Smitková, M. (2018). Fossil fuel energy consumption in European countries. Energy Procedia, 153:

107-111. https://doi.org/10.1016/j.egypro.2018.10.050

[19] Bager, A., Borghi, C.E., Secco, H. (2015). The Influence of Economics, Politics and Environment on Road Ecology in South America. in Handbook of Road Ecology, Chichester, UK: John Wiley \& Sons, Ltd, pp. 407-413.

[20] San Sebastián, M., Hurtig, A.K. (2004). Oil exploitation in the Amazon basin of Ecuador: A public health emergency. Rev. Panam. Salud Publica/Pan Am. J. Public Heal., 15(3): 205-211. https://doi.org/10.1590/S1020-49892004000300014

[21] Acuña, A.J., Pucci, G.N., Tonín, N.L., Tiedemann, C., Pucci, O.H. (2012). Biodegradation of hydrocarbons and cultivable bacterial diversity in Rada Tilly coast line, Patagonia, Argentina. Int. J. Curr. Res., 4(1): 25-29.

[22] Montalván-Burbano, N., Velastegui-Montoya, A., Gurumendi-Noriega, M., Morante-Carballo, F., Adami, M. (2021). Worldwide research on land use and land cover in the amazon region. Sustainability, 13(11). https://doi.org/10.3390/su13116039

[23] Jarvis, A., Touval, J.L., Schmitz, M.C., Sotomayor, L., Hyman, G.G. (2010). Assessment of threats to ecosystems in South America. J. Nat. Conserv., 18(3): 180-188. https://doi.org/10.1016/j.jnc.2009.08.003

[24] Benalcazar, F.L., Valdivieso, S. (2015). Batata 2 remote well pad: Executing sustainable development at a sensitive amazon basin area--decommission and abandonment. Oil Gas Facil., 4(5): 66-72. https://doi.org/10.2118/173555-PA

[25] Tranfield, D., Denyer, D., Smart, P. (2003). Towards a methodology for developing evidence-informed management knowledge by means of systematic review. Br. J. Manag., 14(3): 207-222. https://doi.org/10.1111/1467-8551.00375

[26] Herrera-Franco, G., Montalván-Burbano, N., CarriónMero, P., Jaya-Montalvo, M., Gurumendi-Noriega, M. (2021). Worldwide research on geoparks through bibliometric analysis. Sustainability, 13(3): 1175. https://doi.org/10.3390/su13031175

[27] Pritchard, A. (1969). Statical bibliography or bibliometrics? J. Doc., 25(4): 348-349.

[28] Abad-Segura, E., de la Fuente, A.B., González-Zamar, M.D., Belmonte-Ureña, L.J. (2020). Effects of circular economy policies on the environment and sustainable growth: Worldwide research. Sustainability, 12(14): 5792. https://doi.org/10.3390/su12145792

[29] Herrera-Franco, G., Montalván-Burbano, N., CarriónMero, P., Bravo-Montero, L. (2021). Worldwide research on socio-hydrology: A bibliometric analysis. Water, 13(9): 1283. https://doi.org/10.3390/w13091283

[30] Langenkamp, R.D. (2013). Summary for policymakers. Climate Change 2013 - The Physical Science Basis, 53(9): 1-30.

[31] Sirunyan, A.M., Tumasyan, A., Adam, W., et al. (2018). Observation of the Higgs boson decay to a pair of $\tau$ leptons with the CMS detector. Phys. Lett. B, 779: 283316. https://doi.org/10.1016/j.physletb.2018.02.004

[32] Baas, J., Schotten, M., Plume, A., Côté, G., Karimi, R. (2020). Scopus as a curated, high-quality bibliometric data source for academic research in quantitative science studies. Quant. Sci. Stud., 1(1): 377-386. https://doi.org/10.1162/qss_a_00019

[33] Martín-Martín, A., Orduna-Malea, E., Thelwall, M., Delgado López-Cózar, E. (2018). Google Scholar, Web of Science, and Scopus: A systematic comparison of citations in 252 subject categories. J. Informetr., 12(4): 1160-1177. https://doi.org/10.1016/j.joi.2018.09.002

[34] van Eck, N.J., Waltman, L. (2010). Software survey: VOSviewer, a computer program for bibliometric mapping. Scientometrics, 84(2): 523-538. https://doi.org/10.1007/s11192-009-0146-3

[35] Annunciado, T.R., Sydenstricker, T.H.D., Amico, S.C. (2005). Experimental investigation of various vegetable fibers as sorbent materials for oil spills. Mar. Pollut. Bull., 50(11):

1340-1346. https://doi.org/10.1016/j.marpolbul.2005.04.043.

[36] Muniz, P., Danulat, E., Yannicelli, B., Garcia-Alonso, J., Medina, G., Bicego, M.C. (2004). Assessment of contamination by heavy metals and petroleum hydrocarbons in sediments of Montevideo Harbour (Uruguay). Environ. Int., 29(8): 1019-1028. https://doi.org/10.1016/S0160-4120(03)00096-5.

[37] Cerqueira, V.S., Hollenbach, E.B., Maboni, F., Vainstein, M.H., Camargo, F.A.O., Peralba, M.D.C.R., Bento, F.M. (2011). Biodegradation potential of oily sludge by pure and mixed bacterial cultures. Bioresour. Technol., 102(23):

11003-11010. https://doi.org/10.1016/j.biortech.2011.09.074

[38] Medeiros, P.M., Bícego, M.C., Castelao, R.M., Del Rosso, C., Fillmann, G., Zamboni, A.J. (2005). Natural and anthropogenic hydrocarbon inputs to sediments of Patos Lagoon Estuary, Brazil. Environ. Int., 31(1): 77-87. https://doi.org/10.1016/j.envint.2004.07.001

[39] Medeiros, P.M., Caruso Bícego, M. (2004). Investigation of natural and anthropogenic hydrocarbon inputs in sediments using geochemical markers. I. Santos, SPBrazil. Mar. Pollut. Bull., 49(9-10): 761-769. https://doi.org/10.1016/j.marpolbul.2004.06.001

[40] Simonato, J.D., Guedes, C.L.B., Martinez, C.B.R. (2008). Biochemical, physiological, and histological changes in the neotropical fish Prochilodus lineatus exposed to diesel oil. Ecotoxicol. Environ. Saf., 69(1): 112-120. https://doi.org/10.1016/j.ecoenv.2007.01.012

[41] Trindade, P.V.O., Sobral, L.G., Rizzo, A.C.L., Leite, S.G.F., Soriano, A.U. (2005). Bioremediation of a weathered and a recently oil-contaminated soils from Brazil: A comparison study. Chemosphere, 58(4): 515522. https://doi.org/10.1016/j.chemosphere.2004.09.021

[42] Katsumiti, A., Valdez Domingos, F.X., Azevedo, M., et al. (2009). An assessment of acute biomarker responses in the demersal catfish Cathorops spixii after the Vicuña Oil Spill in a harbour estuarine area in Southern Brazil. 
Environ. Monit. Assess., 152(1-4): 209-222. https://doi.org/10.1007/s10661-008-0309-3

[43] Brandt, R., Merkl, N., Schultze-Kraft, R., Infante, C., Broll, G. (2006). Potential of vetiver (Vetiveria zizanioides (L.) Nash) for phytoremediation of petroleum hydrocarbon-contaminated soils in Venezuela. Int. J. Phytoremediation, 8(4): 273-284. https://doi.org/10.1080/15226510600992808

[44] Guerra, A.B., Oliveiraa, J.S., Silva-Portela, R.C.B. et al. (2018). Metagenome enrichment approach used for selection of oil-degrading bacteria consortia for drill cutting residue bioremediation. Environ. Pollut., 235: 869-880. https://doi.org/10.1016/j.envpol.2018.01.014

[45] de Lima, R.M.G., da Silva Wildhagen, G.R., da Cunha, J.W.S.D., Afonso, J.C. (2009). Removal of ammonium ion from produced waters in petroleum offshore exploitation by a batch single-stage electrolytic process. J. Hazard. Mater., 161(2-3): 1560-1564. https://doi.org/10.1016/j.jhazmat.2008.04.058

[46] Pietzsch, R., Patchineelam, S.R., Torres, J.P.M. (2010). Polycyclic aromatic hydrocarbons in recent sediments from a subtropical estuary in Brazil. Mar. Chem., 118(12):

$56-66$. https://doi.org/10.1016/j.marchem.2009.10.004

[47] Baoune, H., Aparicio, J.D., Acuña, A., El Hadj-khelil, A.O., Sanchez, L., Polti, M.A., Alvarez, A. (2019). Effectiveness of the Zea mays-Streptomyces association for the phytoremediation of petroleum hydrocarbons impacted soils. Ecotoxicol. Environ. Saf., 184: 109591. https://doi.org/10.1016/j.ecoenv.2019.109591

[48] Adetona, O., Li, Z., Sjödin, A., Romanoff, L.C., AguilarVillalobos, M., Needham, L.L., Hall, D.B., Cassidy, B.E., Naeher, L.P. (2013). Biomonitoring of polycyclic aromatic hydrocarbon exposure in pregnant women in Trujillo, Peru - Comparison of different fuel types used for cooking. Environ. Int., 53: 1-8. https://doi.org/10.1016/j.envint.2012.11.010

[49] Gomes, N.C.M., Flocco, C.G., Costa, R., Junca, H., Vilchez, R., Pieper, D.H., Krögerrecklenfort, E., Paranhos, R., Mendonça-Hagler, L.C.S., Smalla, K. (2010). Mangrove microniches determine the structural and functional diversity of enriched petroleum hydrocarbon-degrading consortia. FEMS Microbiol. Ecol., 74(2): 276-290. https://doi.org/10.1111/j.15746941.2010.00962.x

[50] Martins, L.K.P., Nascimento, I.A., Fillmann, G., King, R., Evangelista, A.J.A., Readman, J.W., Depledge, M.H. (2005). Lysosomal responses as a diagnostic tool for the detection of chronic petroleum pollution at Todos os Santos Bay, Brazil. Environ. Res., 99(3): 387-396. https://doi.org/10.1016/j.envres.2005.01.001

[51] Didyk, B.M., Simoneit, B.R.T., Alvaro Pezoa, L., Luis Riveros, M., Anselmo Flores, A. (2000). Urban aerosol particles of Santiago, Chile. Atmos. Environ., 34(8): 1167-1179. https://doi.org/10.1016/S13522310(99)00403-3

[52] Rubio-Clemente, A., Chica, E., Peñuela, G.A. (2015). Petrochemical wastewater treatment by photo-fenton process. Water, Air, Soil Pollut., 226(3): 62. https://doi.org/10.1007/s11270-015-2321-X

[53] Oliveira, M.L.S., Navarro, O.G., Crissien, T.J., Tutikian, B.F., Boit, K., Teixeira, E.C., Cabello, J.J., AgudeloCastañeda, D.M., Silva, L.F.O. (2017). Coal emissions adverse human health effects associated with ultrafine/nano-particles role and resultant engineering controls. Environ. Res., 158: 450-455. https://doi.org/10.1016/j.envres.2017.07.002

[54] Albano, M.J., Lana, P.C., Bremec, C., Elías, R., Martins, C.C., Venturini, N., Muniz, P., Rivero, S., Vallarino, E.A., Obenat, S. (2013). Macrobenthos and multimolecular markers as indicators of environmental contamination in a South American port (Mar del Plata, Southwest Atlantic). Mar. Pollut. Bull., 73(1): 102-114. https://doi.org/10.1016/j.marpolbul.2013.05.032

[55] Ruoppolo, V., Vanstreels, R.E.T., Woehler, E.J., et al. (2012). Survival and movements of Magellanic penguins rehabilitated from oil fouling along the coast of South America, 2000-2010. Mar. Pollut. Bull., 64(7): 13091317. https://doi.org/10.1016/j.marpolbul.2012.05.009

[56] Sangaletti, N., Cea, M., Regitano-d'Arce, M.A.B., de Souza Vieira, T.M.F., Navia, R. (2013). Enzymatic transesterification of soybean ethanolic miscella for biodiesel production. J. Chem. Technol. Biotechnol. https://doi.org/10.1002/jctb.4080 